\title{
Challenges to Studying English Literature by the Saudi Undergraduate EFL Students as Perceived by Instructors
}

\author{
Hammad Ali Alshammari ${ }^{1}$, Elsayed Abdalla Ahmed ${ }^{1} \&$ Mukhled Atta Abu Shouk $^{2}$ \\ ${ }^{1}$ Department of English, College of Arts, Jouf University, Sakaka, Saudi Arabia \\ ${ }^{2}$ Department of English Language Skills, Deanship of Common First Year, Jouf University, Sakaka, Saudi \\ Arabia \\ Correspondence: Hammad Ali Alshammari, Department of English, College of Arts, Jouf University, Sakaka, \\ Saudi Arabia
}

Received: January 3, 2020

Accepted: February 6, 2020

Online Published: February 8, 2020

doi: 10.5539/elt.v13n3p8

URL: https://doi.org/10.5539/elt.v13n3p8

\begin{abstract}
Studying English literature is interrelated to studying English as a foreign language (EFL), and thus incorporating literary texts into EFL learning curricula is important for providing EFL learners with the necessary language skills and emotional growth. However, EFL learners prefer to avoid studying English literature due to several challenges that may extend from difficulties inherited in literature itself to the learning and instructional processes. Therefore, this study aimed at investigating the reasons that may discourage EFL learners to study English literature as perceived by their instructors. The sample of this study consisted of 20 English instructors at one of the northern Saudi universities. Two instruments: a survey and a semi-structured interview developed by the researcher were employed to collect the data. Descriptive statistics and qualitative methods were employed to interpret the gathered data. The findings revealed that there were six main different types of challenges that played an important role in the phenomena under investigation, namely: a) literature inherited difficulty, b) learners' cultural misperceptions, c) learners' negative attitudes, d) learners' intrinsic demotivating factors, e) unfamiliarity/ learners' poor prior knowledge, and f) instructional difficulty. Implications for addressing these problems were included.
\end{abstract}

Keywords: English literature, English literary texts, EFL learners/instructors, teaching/learning, challenges to studying English literature

\section{Introduction}

The Saudi undergraduate English as a foreign language (EFL) learners experience a set of learning difficulties that can be the source of their overall poor performance in language skills. Their weaknesses in learning language skills stem mainly from the inadequate practice of these skills, poor learning habits, inappropriate EFL curriculum, and ineffective instruction. Intensive previous research suggests that incorporating authentic content into undergraduate EFL learning and instruction would considerably upgrade learners' levels in English. One vital suggested type of authentic learning materials is English literature which has been neglected in the EFL learning materials. It is believed that incorporating literature in the Saudi EFL learning setting would bridge the gap between the current poor performance level in English skills of EFL learners and the desired learning outcomes.

The EFL programs at public universities are supported with up-to-date materials and resources at the highest levels, however, it is believed that the current instruction and materials are still below expectations and need to be improved, especially offering authentic-based curricula. Providing EFL learners with daily practices on literature-related tasks is believed to promote their motivation levels as well as their attitudes toward mastering the necessary English skills.

However, studies have revealed that the Saudi EFL learners tend to avoid learning English literature for various reasons. For example, previous research indicated that second language learners were demotivated to study texts of English literature for different cultural, attitudinal, and emotional barriers (Hussein \& Al-Emami, 2016). Some studies proved that EFL learners misperceived English literature as the most difficult part of their English learning with its ambivalent vocabulary, sentences, ideas, and complicated actions. It was also found that EFL 
learners were uninterested in learning English literature because most EFL assessment tasks ignored the literature text.

Therefore, EFL learners whose study of English is exam-driven rely mostly on memorizing strategies taking them far away from the analytical, synthetic, critical, and evaluative levels required for literature study (Sayed, 2003). This traditional learning method may not enable EFL learners to acquire high-order thinking skills in English and thus contribute negatively to their intrinsic and extrinsic motivation to learning English literature (Alhamdi, 2014; Al-Hazmi, 2003). Therefore, a deeper understanding of the possible reasons that demotivate the Saudi undergraduate EFL learners to study English literature and proposing meaningful related solutions are the main drive for this research.

\section{Background}

Incorporating English literary texts into EFL curricula has long been a topic of debate among scholars in the field of teaching and learning EFL (e.g Swaffar, 2000; Dupuy, 2000, Rice,1991; Lima, 2010; Tamo, 2009). Many scholars like McKay, (1982) Khdhir \& Mariwan (2016), Rashid \& Mariwan (2017), and Khatib, Rezaei \& Derakhshan (2011) believe that the advantages of integrating literary texts into EFL classes outweigh its disadvantages and the authentic content of English textbooks would help second language learners to improve their overall perception and practice of the target language skills. These texts could also help EFL learners promote their grammatical awareness and overall proficiency (Tayebipour, 2009).

A recent study published by Alshammari \& Elsayed (2019) has examined the impact of exposing college students to English literature through an intensive training program using an English novel as an authentic language reference. The study employed a pre-and-post language performance test to explore the influence of English literature on the improvement of the overall language skills of participants. It was found that there were some challenges EFL learners encountered at the initial stage of the experience; however, all participants' overall language skills were improved with a specific increase in their metalinguistic awareness.

Parkinson and Thomas (2000) suggest that the authentic nature of literary texts provides students with mental training and expands their knowledge not only about language but about life in general. It is also believed that "reading is the most autonomous ability in language work, and literature is a rich and widely-appealing source of material for reading." (Brumfit, 1981, p. 105). However, integrating English literature into a language learning setting was found to be difficult which called for the need to bridge the gap between the theoretical design of the EFL curriculum and its relevant practical use (Lima, 2005).

According to the researcher's observation and experience in the field of teaching EFL and English literature, it is strongly believed that the English literature texts are easier to be studied and perceived by high achievers than the low level students. This observation is supported by Krishnasamy (2015) who suggests that studying English literature correlates with EFL learners' level of proficiency where stronger ones find it easier than low achievers. In a similar context, Işıklı \& Tarakçığlu (2017) explored the problems of implementing English literature course in high schools in Turkey using a survey and an English proficiency test to collect the data. They found that the low proficiency level of participants was the most influential factor that prevented them from studying the literature course successfully.

According to Krishnasamy (2015), unless the EFL program reflects students' real levels of proficiency there would be a risk of producing "a mismatch between the literary text and students' language ability" which would inevitably have a negative effect on the course implementation (p.139). In fact, learners normally read and translate the words, but find it difficult to interpret and understand the ideas since literature is unfamiliar to them. Parkinson and Thomas (2000) strongly believe that the remoteness of a particular text and the use of odd language can be challenging for EFL students.

Studying English literature cannot be separated from studying the language irrespective of the learner's real proficiency level. Leech (1996) states, "we generally suppose that the literature cannot be examined in any depth apart from the language, any more than the language cannot be studied apart from the literature" (p.1). However, literature was neglected and more attention was given to conversations that were believed to be more practical and visible in the real world situation (Khatib et al., 2011).

One important perspective that plays a crucial role in defining and identifying the challenges encountered studying English literature is the student's perception in this regard. Al-Mahrooqi \& Al-Wahaibi (2012) investigated EFL learners' perceptions and attitudes towards studying English literature courses and found that the more courses they took, the more positive they were about literature. This is why Brumfit (1981) encourages teaching literature to EFL learners in spite that it could be difficult. However, learner's inability to understand 
literature due to their deficient proficiency in English and their poor reading skills may be the major reasons that hinder their learning of English literature.

Learners' proficiency level may not be the only reason that leads students to avoid studying literature courses. Krishnasamy (2015) found that EFL learners were generally not interested in the literature of the target language. In fact, the researcher's observations also indicate that many EFL learners misperceive English literature thinking that it contradicts their own culture, values, and beliefs. Other learners generally dislike studying literature whether it is written in the first language or the target one, which complicates the issue and calls for the need to reconstruct their motives and appreciation of literature. For example, Hussein \& Al-Emami (2016) found that the source of problems EFL learners encounter when studying English literature is mostly attributed to the low level of proficiency in English, the difficult literature text offered to learners, and the cultural familiarity.

Claiming that the cultural barriers prevent EFL learners from studying literature of the target language and discourage the inclusion of literary texts in the EFL curriculum maybe unreasonable. However, it would be reasonable that the EFL learner finds it difficult to study and understand deep literature texts that are mostly offered with specific requirements such as learners' need to be equipped with a rich understanding of English vocabulary and their usage.

Investigating these challenges with fresh enrolled EFL learners at the college level would lead to complicating what is already complicated. That is why this research attempted to investigate this phenomenon among EFL learners with higher language levels who mastered the basics of English where the relevant literature analysis is more familiar for them than their freshmen counterparts. Therefore, this research aims at finding out the most salient challenges that discourage EFL learner to successfully study English literature. It is hoped that the results and conclusion of this research would assist the EFL learners to understand these barriers and overcome them more smoothly. The findings of this research would also be significant for researchers in the field to conduct further related studies, and for EFL curriculum planners and designers for a better understanding of the literature needs of learners. Therefore, this research attempted to answer the following two questions:

RQ1: Why do the Saudi undergraduate EFL learners avoid studying English literature?

RQ2: How can English literature be positively appreciated by the Saudi undergraduate EFL learners?

\section{Method}

The data on the challenges that hindered the successful study of literature by the EFL Saudi undergraduate English major students were collected through two instruments: 1) a survey with ten open-ended items all of which were answered on a 5-point Likert-type scale, with $5=$ strongly agree to $1=$ strongly disagree and an option for comments and 2) a short semi-structured interview developed in light of the questionnaire findings. The sample of respondents consisted of 20 college instructors currently teaching English literature courses in the department of English at one of the northern Saudi universities for a minimum of two year-experience with an average age of 40 years. The respondents were 10 males and 10 females from various cultural backgrounds. Data was analyzed first collectively from both sample types (male and females) and then independently (male responses were separated from females using a mixed approach of quantitative and qualitative methods. The participants' responses to the questionnaire were analytically interpreted in terms of frequencies and percentages as well as means and standard deviations as follows:

- Mean values of Strongly agree are equal to 4-5 points,

- Mean values of Agree are equal to 3-3.9 points,

- Mean values of Don't know are equal to 2-2.9 points,

- Mean values of Disagree are equal to 1-1.9 points, and

- Mean values of Strongly disagree are equal to - 1 point.

Respondents comments on the questionnaire items and their and open-ended responses to the interview items were transcribed, organized, codded and interpreted qualitatively.

\section{Results}

This study attempted to find out the main possible reasons and challenges that might prevent EFL undergraduate learners in Saudi Arabia from studying English literature. In other words, this research tried to dig deep into the demotivating factors, whether they were intrinsic in the learners themselves or extrinsic in the teaching process, that discouraged studying literary texts by the EFL learners as perceived by their instructors. This research also tried to find out the possible methods that the EFL instructors believed to push the Saudi learners to appreciate 
and study English literature. Therefore, the findings of this study are displayed below in order with the two main research questions mentioned above: 1) Why do the Saudi undergraduate EFL learners avoid studying English literature (challenges encounter studying English literature by EFL learners)? or, And 2) How can English literature be positively appreciated by the Saudi undergraduate EFL learners?

\subsection{Challenges Encounter Studying English Literature}

The descriptive analysis of the questionnaire items related to the challenges encountered EFL learners to study English literature indicated that there were six main categories of sources for the phenomenon under investigation, namely: literature inherited difficulty (items 1 and 9), learners' cultural misperceptions (item 3), learners' negative attitudes (items 4 and 10), learners' intrinsic demotivating factors (items 5,6 and 7), unfamiliarity/ learners' poor prior knowledge (item 8) and instructional difficulty (item 2).

\subsubsection{First: Literature Inherited Difficulty}

Table 1 shows that most male and female respondents strongly agreed/agreed (90\%) that "The Saudi EFL learners find English literature difficult" (item 1), and (70\%) of them reported similar response regarding item 9 (The Saudi EFL learners perceive English literature as literary texts of complex contents) with mean values of $(\mathrm{M}=4.4, \mathrm{SD}=1.15$ and 3.9; $\mathrm{SD}=1.17$ respectively). The responses of male instructors to these items $(\mathrm{M}=4.8$, $S D=.042 \& \mathrm{M}, 4.4 S D=1.07$ respectively) were similar to and consistent with that of females $(\mathrm{M}=4, S D=$ $1.15 \& \mathrm{M}=3.4 \mathrm{SD}=1.17$ respectively) as shown in tables 2 and 3 . This finding indicated that male and female EFL instructors believed that one of the main reasons underlying the difficulty of studying English literature by their students was inherited in the offered literary texts.

\subsubsection{Second: Learners' Cultural Misperception}

Table 1 shows that most male and female respondents strongly agreed/agreed (65\%) that " The Saudi EFL learners find most English literary texts culturally inappropriate" (item 3) with a mean value of $(\mathrm{M}=3.55 \mathrm{SD}=$ 1.51). The responses of male instructors to this item $(\mathrm{M}=3.7, S D=1.25 \& \mathrm{M}, 4.4 S D=1.07$ respectively) were similar to and consistent with that of females $(\mathrm{M}=4, S D=1.15 \& \mathrm{M}=3.4 \quad S D=1.17$ respectively) as shown in tables 2 and 3. This indicates that EFL learners misperceived English literature as inappropriate and threatening to their own culture.

Table 1. Descriptive statistics of male and female instructors' responses

\begin{tabular}{|c|c|c|c|c|c|c|c|c|c|c|c|c|}
\hline \multirow[b]{2}{*}{$\begin{array}{c}\text { Item } \\
\#\end{array}$} & \multicolumn{9}{|c|}{ Frequency } & \multirow[b]{2}{*}{$d^{\circ}$} & \multirow[b]{2}{*}{ Mean } & \multirow[b]{2}{*}{$S T D$} \\
\hline & 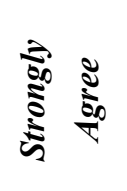 & de & $\frac{\tilde{\nu}}{\tilde{\nabla}}$ & de & $\frac{a}{5}$ & de & 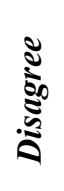 & $d e$ & 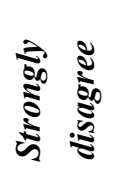 & & & \\
\hline 1. & 12 & 60 & 6 & 30 & 0 & 0 & 2 & 10 & 0 & 0 & 4.4 & 1.15 \\
\hline 2. & 7 & 35 & 2 & 10 & 0 & 0 & 5 & 25 & 6 & 30 & 2.9 & 1.20 \\
\hline 3. & 7 & 35 & 6 & 30 & 3 & 15 & 3 & 15 & 2 & 10 & 3.55 & 1.51 \\
\hline 4. & 16 & 80 & 3 & 15 & 0 & 0 & 1 & 5 & 0 & 0 & 4.7 & 0.32 \\
\hline 5. & 17 & 85 & 2 & 10 & 0 & 0 & 0 & 0 & 0 & 0 & 4.8 & 0.70 \\
\hline 6. & 17 & 85 & 1 & 5 & 0 & 0 & 2 & 10 & 0 & 0 & 4.65 & 0.97 \\
\hline 7. & 9 & 45 & 4 & 20 & 2 & 10 & 4 & 20 & 1 & 5 & 3.8 & 0.71 \\
\hline 8. & 10 & 50 & 4 & 20 & 1 & 5 & 2 & 10 & 1 & 5 & 4.1 & 1.37 \\
\hline 9. & 8 & 40 & 6 & 30 & 3 & 15 & 2 & 10 & 1 & 5 & 3.9 & 1.17 \\
\hline 10. & 0 & 0 & 1 & 5 & 1 & 5 & 3 & 15 & 15 & 75 & 1.4 & 0.97 \\
\hline
\end{tabular}




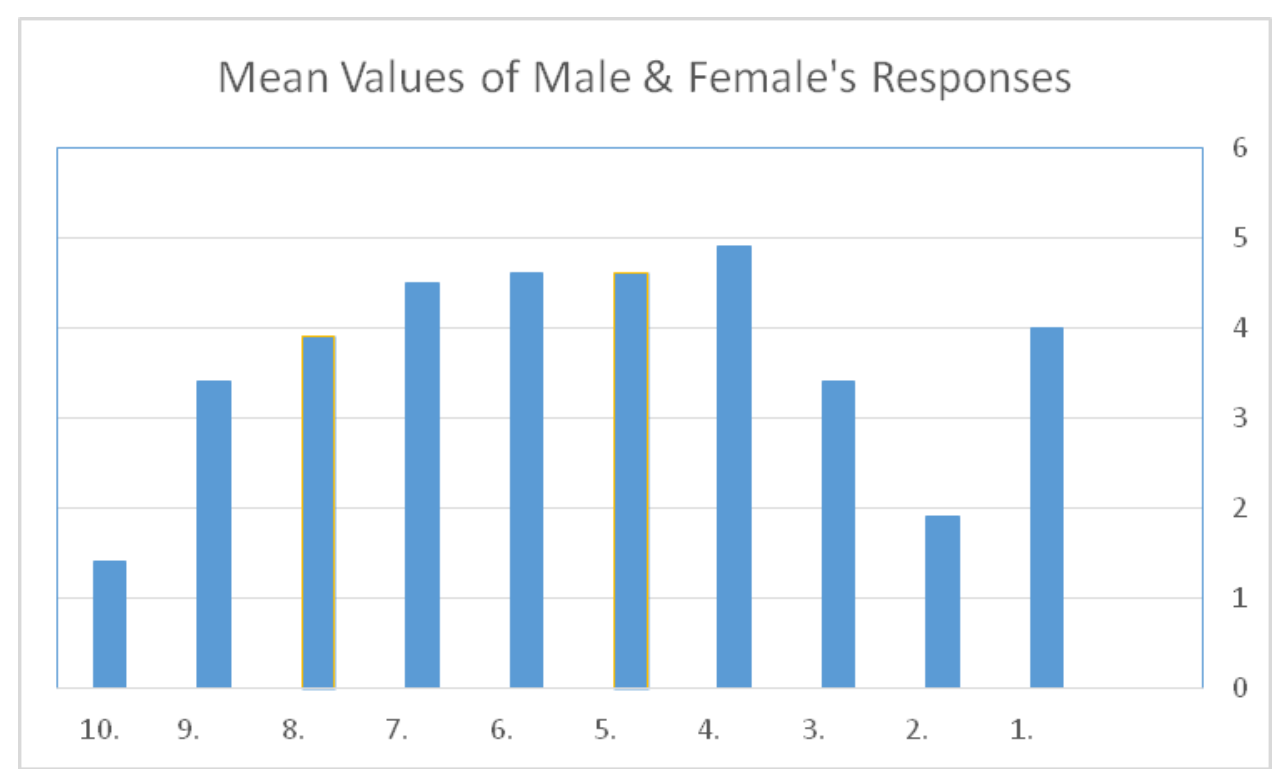

Figure 1. Mean values of male $\&$ female responses to the questionnaire items

Table 2. Descriptive statistics of male instructors' responses

\section{Frequency}

\begin{tabular}{|c|c|c|c|c|c|c|c|c|c|c|c|c|}
\hline $\begin{array}{c}\text { Item } \\
\#\end{array}$ & 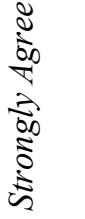 & de & $\frac{\check{\nu}}{\Delta 0}$ & de & 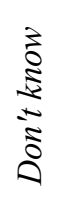 & de & 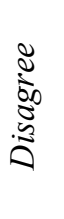 & de & 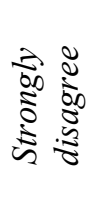 & de & Mean & $S T D$ \\
\hline 1. & 8 & 80 & 2 & 20 & 0 & 0 & 0 & 0 & 0 & 0 & 4.8 & 0.42 \\
\hline 2. & 7 & 70 & 0 & 0 & 0 & 0 & 2 & 20 & 1 & 10 & 3.9 & 1.60 \\
\hline 3. & 4 & 40 & 1 & 10 & 3 & 30 & 2 & 20 & 0 & 0 & 3.7 & 1.25 \\
\hline 4. & 7 & 70 & 2 & 20 & 0 & 0 & 1 & 10 & 0 & 0 & 4.5 & 0.97 \\
\hline 5. & 10 & 100 & 0 & 0 & 0 & 0 & 0 & 0 & 0 & 0 & 5 & 0.00 \\
\hline 6. & 9 & 90 & 0 & 0 & 0 & 0 & 1 & 10 & 0 & 0 & 4.7 & 0.95 \\
\hline 7. & 3 & 30 & 1 & 10 & 1 & 10 & 4 & 40 & 1 & 10 & 3.1 & 1.52 \\
\hline 8. & 6 & 60 & 2 & 20 & 1 & 10 & 1 & 10 & 0 & 0 & 4.3 & 1.06 \\
\hline 9. & 7 & 70 & 1 & 10 & 1 & 10 & 1 & 10 & 0 & 0 & 4.4 & 1.07 \\
\hline 10 . & 0 & 0 & 0 & 0 & 1 & 10 & 2 & 20 & 7 & 70 & 1.4 & 0.70 \\
\hline
\end{tabular}




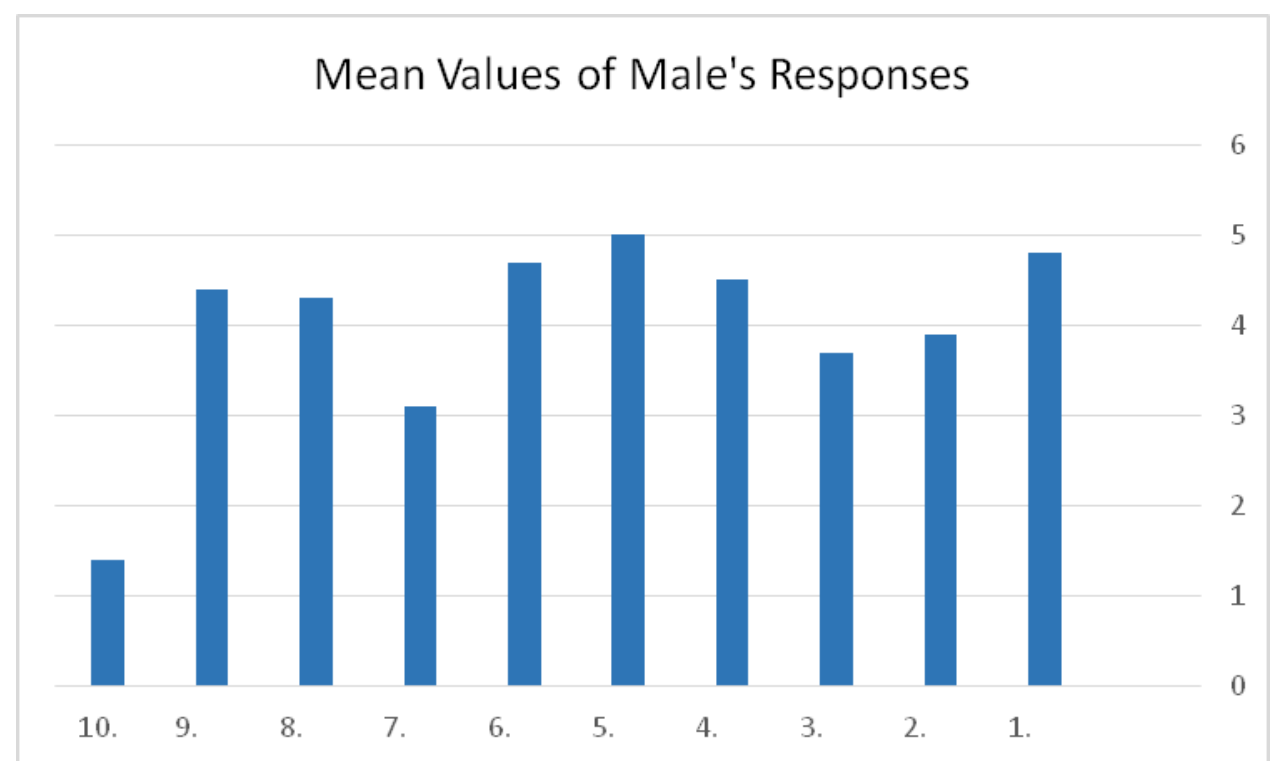

Figure 2. Mean values of male's responses

Table 3. Descriptive statistics of female instructors' responses

\begin{tabular}{|c|c|c|c|c|c|c|c|c|c|c|c|c|}
\hline \multirow[b]{2}{*}{$\begin{array}{c}\text { Item } \\
\#\end{array}$} & \multicolumn{9}{|c|}{ Frequency } & \multirow[b]{2}{*}{$d e$} & \multirow[b]{2}{*}{ Mean } & \multirow[b]{2}{*}{$S T D$} \\
\hline & 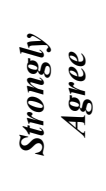 & de & 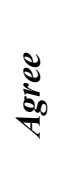 & $d e$ & 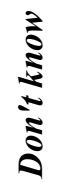 & de & 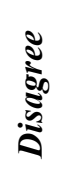 & $d \theta$ & 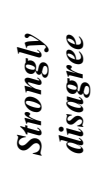 & & & \\
\hline 1. & 4 & 40 & 4 & 40 & 0 & 0 & 2 & 20 & 0 & 0 & 4 & 1.15 \\
\hline 2. & 0 & 0 & 2 & 20 & 0 & 0 & 3 & 30 & 5 & 50 & 1.9 & 1.20 \\
\hline 3. & 2 & 20 & 5 & 50 & 0 & 0 & 1 & 10 & 2 & 20 & 3.4 & 1.51 \\
\hline 4. & 9 & 90 & 1 & 10 & 0 & 0 & 0 & 0 & 0 & 0 & 4.9 & 0.32 \\
\hline 5. & 7 & 70 & 2 & 20 & 1 & 10 & 0 & 0 & 0 & 0 & 4.6 & 0.70 \\
\hline 6. & 8 & 80 & 1 & 10 & 0 & 0 & 1 & 10 & 0 & 0 & 4.6 & 0.97 \\
\hline 7. & 6 & 60 & 3 & 30 & 1 & 10 & 0 & 0 & 0 & 0 & 4.5 & 0.71 \\
\hline 8. & 4 & 40 & 4 & 40 & 0 & 0 & 1 & 10 & 1 & 10 & 3.9 & 1.37 \\
\hline 9. & 1 & 10 & 5 & 50 & 2 & 20 & 1 & 10 & 1 & 10 & 3.4 & 1.17 \\
\hline 10. & 0 & 0 & 1 & 10 & 0 & 0 & 1 & 10 & 8 & 80 & 1.4 & 0.97 \\
\hline
\end{tabular}




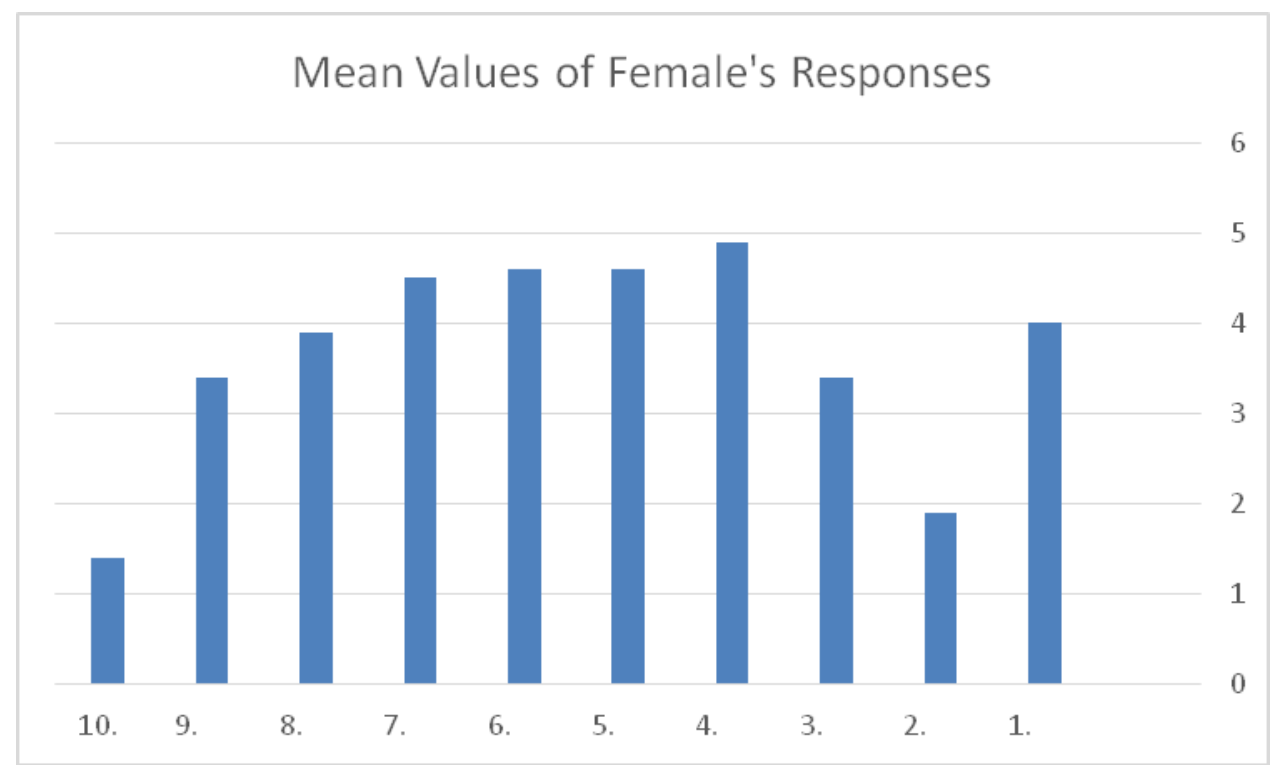

Figure 3. Mean values of female's responses

\subsubsection{Third: Learners' Negative Attitudes}

Table 1 shows that most male and female respondents strongly agreed (95\%) that " The Saudi EFL learners underestimate the importance of English literature in improving their mastery of English language skills (item 4) with a mean value of $(\mathrm{M}=4.7, \mathrm{SD}=0.32)$, and $(70 \%)$ of them disagreed that "The Saudi EFL learners believe that English literature is a non-supportive field for their overall learning goals" (item 10) with a mean value of $(\mathrm{M}=1.4 ; \mathrm{SD}=0.97)$. The responses of male instructors to item $4(\mathrm{M}=4.5, S D=.042 \& \mathrm{M}, 4.4 S D=1.07$ respectively) were similar to and consistent with that of females $(\mathrm{M}=4, S D=1.15 \& \mathrm{M}=3.4 \quad S D=1.17$ respectively) as shown in tables 2 and 3. This finding revealed that the EFL learners found English literature unimportant despite that it might support their learning.

\subsubsection{Fourth: Learners' Intrinsic Demotivating Factors}

Table 1 shows that the total responses of male and female instructors strongly agreed that the EFL learners' intrinsic demotivating factors: (item 5: The Saudi EFL learners avoid studying English literature due to their poor language proficiency level, item 6: The Saudi EFL learners avoid studying English literature as literary materials even in their L1 (Arabic), and item 7: The Saudi EFL learners believe that studying English literature wouldn't help them get proper jobs in future) with mean values of ( M, 4.6 STD $=0.70 ; \mathrm{M}, 4.6 \quad S T D=0.97$ \& $\mathrm{M}, 4.5 S T D=0.71)$. As shown in tables 2 and 3, the responses of the male instructors, on the one hand, and that of females, on the other hand, were consistent with these findings. These findings indicate that learners' poor proficiency levels, negative desire to study literature and negative beliefs about literature usefulness for future jobs were believed to be some reasons beyond avoiding studying English literature.

\subsubsection{Fifth: Unfamiliarity/ Learners' Poor Prior Knowledge}

Table 1 shows that most male and female instructors (70) strongly agreed/agreed that the learners' poor prior knowledge or unfamiliarity with the English literature were sources of the phenomenon under investigation. The total responses to item 8: The Saudi EFL learners believe that studying English literature is unfamiliar for them) proved this level of agreement with a mean value of ( M, $3.9 \quad S T D=1.37)$. Tables 2 and 3 also proved the consistency of male instructors, on the one hand, and that of females, on the other hand. This refers to the fact that EFL learners were generally rarely exposed to English literature and found it unfamiliar for them which requires them to do further efforts and learning processing when they were normally exposed to.

\subsubsection{Sixth: Instructional Difficulty}

Table 1 shows that the respondents were uncertain whether their role as instructors of English literature was difficult or not. More than half of the respondents (55\%) strongly disagreed/disagreed that "Teaching English literature to Saudi EFL learners is difficult" (Item 2), while around (45\%) of respondents either strongly agreed/agreed that it was difficult. The average of all male and female participants' responses showed uncertainty with a mean value of $(\mathrm{M}=2.9, \mathrm{SD}=1.20)$. Taking the male instructors' responses only shows an agreement with this difficulty with a mean value of $(\mathrm{M}=3.9, \mathrm{SD}=1.60)$, while female instructors disagreed with this item with a 
mean value of $(\mathrm{M}=1.9, \mathrm{SD}=1.20)$. These findings revealed a controversy among EFL instructors regarding the difficulty level they encounter when teaching English literature.

The qualitative analysis of the participants' responses to the two main questions of the interview revealed similar findings. Most instructors (males and females) believed that studying English literature successfully required an advanced proficiency level of EFL learners. They reported that the poor knowledge and skills of language would form a serious concern in the face of learning literary texts. A female instructor literally stated that it is "... all about language poor performance... most Saudi EFL learners escape form studying English literature due to their poor language knowledge, or vocabulary as well as poor reading skills". One instructor wondered "how would students understand literature without mastering the tool of understanding, that is knowing the meaning of the words".

The analysis of instructors' responses also revealed that they perceived EFL learners as passive recipients of English literature. Some of them claimed that learners relied heavily on the teacher-centeredness as the only source for their learning. Some respondents reported that learners compensate their poor proficiency levels and misperception of literature as well as negative attitudes towards English literature by relying on this unidirectional mode of study i.e, the instructors direct, teach and assess with passive roles for learners.

Some interviewees claimed that their students were uninterested in studying English literature or even in their L1 literature due to their misperceptions and/or underestimation of the role of literature in both their language learning or future jobs. One instructor said, " My students usually link literature to the historic, out-of-date unimportant genre of prose or poetry that is normally far away from our need or ability ". He added, " They (students) think that studying literature won't help them master language skills which are of communicative nature for nowadays interactions".

The analysis of responses to the interview also revealed that the study of literature is demanding for EFL learners due to its unfamiliarity. A male instructor said, " My students have never been exposed to literary texts before getting level 5 or 6 at university.

However, respondents appeared to look for solutions rather than addressing the issue. Although most of them suggested the need for improving learner's language proficiency, some respondents thought out of the box and proposed various instructional and curricular solutions. For instance, one female instructor proposed to incorporate literature circles in the teaching techniques, another one suggested including simplified literature texts in the curriculum. One last solution was from a male instructor who proposed to link the study of English literature to multimedia techniques i.e., exposing EFL learners to literary texts simultaneously with their depicted representations in the media.

One last view appeared to link problems of studying English literature to the inappropriate content of the offered literary texts. In fact, there were some indications that ELF learners appeared to be sensitive regarding values and cultures of the target language; however, this claim was unlikely reasonable since literary texts offered to students were carefully selected and took into consideration the cultural sensitivity.

\section{Discussion}

Investigating the challenges that EFL learners face when they are exposed to literary texts of the target language reflects the importance of literature not only in empowering the proficiency of learners' language or helping them to positively view the target language but also in providing them with interesting learning methods and bridging the gap between their current negative perceptions of literature and its important role in the civilized world. Literature is the mirror of nations, and thus studying it can never be separable from studying its language. The present study attempted to find out why EFL learners avoided studying English literature and found a range of reasons for this phenomenon. It has been revealed that these challenges were mostly attributed to EFL learners' factors. However, this discussion addresses what has been revealed as perceived by EFL instructors taking into account the need for some balance in looking for solutions.

The findings of this research indicated that EFL learners find it challenging to study English literature due to the difficulty of literary texts. This is true to a certain extent and supported by previous research as mentioned above. However, English literary texts are not all of a similar level of difficulty. These texts can be simplified and displayed in an interesting aesthetic manner. Literature per se, whatever genre it is, prose, drama, novel, or poetry is originally created as innovative texts for the aim of making life more enjoyable, better viewed and deeper understood. Therefore, the researchers believe that this challenge is not in literature per se, rather it is in the ways and forms the literature is offered through to the EFL learners, especially the ineffective instruction or poor curricular designs. It is also believed that literature, like any other learning material, should be included in 
the EFL curriculum with a gradual sequence of difficulty. For example, deep literary texts that require high thinking-order skills to understand and enjoy should be delayed to the last sage of the learning process, while easier texts should be presented in an earlier stage.

Learners' misperception of English literature as inappropriate and threatening to their culture resulted from their misunderstanding of the word 'literature' itself which was rarely interpreted to them with live examples. Besides that, EFL learners would normally prefer studying easier communicative texts since they are mostly instrumentally driven to language study. i.e., they are exam-driven students and job seekers rather than integrative-driven to language study. Such misperceptions can be easily addressed if the language instructors were more effective teachers of language and literature, if curricular designers incorporated suitable literary texts, and if learning outcomes included real aesthetic dimensions in language learning such as learning for enjoyment. As long as English literature is offered to EFL learners through conventional instructional approaches and poorly designed curricula, learners would normally continue demotivated and believe that it is an unsupportive activity for their learning.

Unfamiliarity, poor proficiency levels, poor prior background knowledge and negative attitudes of EFL learners, poor instruction and inappropriate curricula all share the responsibility about the phenomenon under investigation. Therefore, the blame should not be set on the shoulders of learners alone.

\section{Conclusion}

This research has shed light on the main problems that encounter studying English literature by EFL learners as perceived by their instructors. A set of challenges that were mostly attributed to learners themselves were revealed. However, the researchers believe that in order to solve these serious issues, responsibility should be shared amongst the learners, instructors, and curriculum designers. Most importantly, the English curriculum in the Saudi educational system should incorporate literary texts from the early stages. At the advanced levels of undergraduate EFL programs, the curriculum should include well-designed and sequenced literature texts and activities that take into account the difficulty level of these selected texts and the current learners' abilities and proficiency levels. There are numerous attractive examples of literary content that have been depicted in media and suit learners. These examples can improve learners' attitudes toward literature, push them to study English literature and improve their proficiency level. Therefore, such works can improve the overall performance and appreciation of learners towards English literature. These examples include, and may not be limited to, the Merchant of Venice for William Shakespeare, Death of a Salesman for Arthur Muller, the King of Flies for William Golding, the Animal Farm for George Orwell and Jouf History for Hammad Alshammari, which is a popular local documentary of prose and poetry (English version). These literary text have been produced as attracting movies and can be displayed to EFL learners simultaneously with the written texts.

It is suggested that further research should be conducted on the importance of integrating portrayed literature into written EFL literature curriculum and the related impacts on improving learners' English proficiency levels and attitudes towards literature.

\section{References}

Alhamdi, N. (2014). English Speaking Learning Barriers in Saudi Arabia: A Case Study of Taibah University. Arab World English Journal, 5(2), 38-53. ISSN: 2229-9327. https://doi.org/10.35631/ijhpl.28003

Al-Hazmi, S. (2003). EFL teacher preparation programs in Saudi Arabia: Trends and challenges. TESOL Quarterly, 37(2), 341-344. https://doi.org/10.2307/3588509

Al-Mahrooqi R. \& Al-Wahaibi T. (2012). EFL Student Attitudes towards Studying Literature at a Higher Education Institution in Oman. European Journal of Social Sciences, 32(1), 77-83 retrieved on Dec. 12th, 2019 from: https://www.researchgate.net/publication/283122793_EFL_Student_Attitudes_towards_Studying_Literatur e_at_a_Higher_Education_Institution_in_Oman

Alshammari, H. \& Elsayed A. (2019). Using an English Novel to Improve Saudi EFL Reading Skills. Education and Linguistics Research, 5. https://doi.org/10.5296/elr.v5i2.14710

Brumfit, C. J. (1981). Language and Literature Teaching: From Practice to Principle (pp.105-110). Oxford: Pergam on Press.

Dupuy, B. (2000). Content-based instruction: Can it help ease the transition from beginning to advanced foreign language classes? Foreign Language Annals, (33), 205-223. https://doi.org/10.1111/j.1944-9720.2000.tb00913.x 
Hussein, T. \& Al-Emami, H. (2016). Challenges to teaching English literature at the university of Hail: instructors' perspective. Arab World English Journal (AWEJ), 7(4), 125-138. https://dx.doi.org/10.24093/awej/vol7no4.9

Işıklı, C. \& Tarakçıŏlu, A. (2017). Investigating problems of English literature teaching to EFL high school students in Turkey with focus on language proficiency. Journal of Language and Linguistic Studies, 13(2), 82-95. https://files.eric.ed.gov/fulltext/EJ1159172.pdf

Khatib, M., Rezaei, S. \& Derakhshan, A. (2011). Literature in EFL/ESL Classroom [Electronic Version]. English Language Teaching, 4(1), 201-208. https://doi.org/10.5539/elt.v4n1p201

Khdhir, H \& Mariwan N. (2016). The Importance of Literary Texts in Teaching Language in EFL Classes: The Waste Land as an Example. International Journal of Literature and Arts, 4(1), 1-6. https://doi.org/10.11648/j.ijla.20160401.11

Krishnasamy, J. (2015). An Investigation of Teachersee Approaches Employed in Teaching the English Literature. Asian Journal of Education and e-Learning (ISSN: 2321 -2454), 2(3).

Leech, G. N. (1996). A linguistic guide to English poetry. New York, NY: Longman.

Romero, E. D. \& Bobkina, J. (2015). Literature mediated English in the UCM degree in modern languages: a pilot study. Theory and Practice in Language Studies, 5(2), 235-246.

Lima, C. (2010). Selecting Literary Texts for Language Learning. Journal of NELTA, 15(1-2), 110-114. https://doi.org/10.3126/nelta.v15i1-2.4616

McKay, S. (1982). Literature in ESL Classrooms. TESOL Quarterly, 16(4), Dec. 529-536. https://doi.org/10.2307/3586470

Parkinson, B. \& Thomas, H. (2000). Teaching Literature in a Second Language (pp.9-13). Edinburgh: Edinburgh University Press.

Rashid, B. \& Mariwan H. (2017). The Significance of Literary Texts in Pedagogy of English Language in EFL/ESL Classroom. International Review of Social Sciences, 5, 52-57

Rice, D. (1991). Language proficiency and textual theory: How the train might meet. ADFL Bulletin, 22(3), 12-15. https://doi.org/10.1632/adfl.22.3.12. ISBN: 0148-7639

Sayed, Z. (2003). The Sociocultural Context of English Language Teaching in the Gulf. TESOL Quarterly, 37(2), 337-341. https://doi.org/10.2307/3588508

Swaffar, J. (1999). The case for foreign languages as a discipline. ADFL Bulletin, (30), 6-12. https://doi.org/10.1632/adfl.30.3.6

Tamo, D. (2009). The Use of Authentic Materials in Classrooms. LCPJ, 2(1), 74-78. https://doi.org/10.3126/nelta.v11i1.3117 ISBN: 2091-0487

Tayebipour, F. (2009). In Defense of Teaching literature to EFL students in the era of Globalization. In R. R. L. $J$. Zhang (ed.), Englishes and Literatures-in-English in a Globalised World: Proceedings of the 13th International Conference on English in Southeast Asia. (pp. 213-219). Singapore: National Institute of Education. 


\section{Appendix A}

\section{EFL Instructors' Questionnaire}

\begin{tabular}{|c|c|c|c|c|c|c|}
\hline \# & Item & 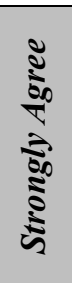 & $\frac{\stackrel{2}{\pi}}{20}$ & $\begin{array}{l}\overline{\mathbf{z}} \\
\bar{z} \\
\bar{z}\end{array}$ & $\frac{2}{3}$ & 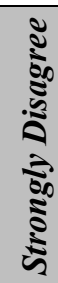 \\
\hline 1 & The Saudi EFL learners find English literature difficult. & 5 & 4 & 3 & 2 & 1 \\
\hline 2 & $\begin{array}{c}\text { Teaching English literature to Saudi EFL learners is } \\
\text { difficult. }\end{array}$ & 5 & 4 & 3 & 2 & 1 \\
\hline 3 & $\begin{array}{c}\text { The Saudi EFL learners find most English literary texts } \\
\text { culturally inappropriate. }\end{array}$ & 5 & 4 & 3 & 2 & 1 \\
\hline 4 & $\begin{array}{l}\text { The Saudi EFL learners underestimate the importance of } \\
\text { English literature in improving their mastery of English } \\
\text { language skills. }\end{array}$ & 5 & 4 & 3 & 2 & 1 \\
\hline 5 & $\begin{array}{l}\text { The Saudi EFL learners avoid studying English literature due } \\
\text { to their poor language proficiency level. }\end{array}$ & 5 & 4 & 3 & 2 & 1 \\
\hline 6 & $\begin{array}{c}\text { The Saudi EFL learners avoid studying English literature as } \\
\text { literary materials even in their L1 (Arabic). }\end{array}$ & 5 & 4 & 3 & 2 & 1 \\
\hline 7 & $\begin{array}{l}\text { The Saudi EFL learners believe that studying English } \\
\text { literature wouldn't help them get proper jobs in the future. }\end{array}$ & 5 & 4 & 3 & 2 & 1 \\
\hline 8 & $\begin{array}{l}\text { The Saudi EFL learners believe that studying English } \\
\text { literature is unfamiliar to them. }\end{array}$ & 5 & 4 & 3 & 2 & 1 \\
\hline 9 & $\begin{array}{l}\text { The Saudi EFL learners perceive English literature as literary } \\
\text { texts of complex contents. }\end{array}$ & 5 & 4 & 3 & 2 & 1 \\
\hline 10 & $\begin{array}{l}\text { The Saudi EFL learners believe that English literature is a } \\
\text { non-supportive field for their overall learning goals. }\end{array}$ & 5 & 4 & 3 & 2 & 1 \\
\hline
\end{tabular}




\section{Appendix B}

\section{Semi-Structured Interview Format}

Question 1: Why do you think the Saudi undergraduate EFL learners avoid studying English literature? Mention as many reasons as possible?

Question 1: what do you think about the role of the following challenges, if not mentioned earlier, in preventing EFL learners from studying English literature?

a. Learners poor proficiency level:

b. Learner's negative attitudes towards English literature:

c. Learner's underestimation of English literature:

d. Learner's cultural sensitivity toward English literature:

e. Learner's poor prior knowledge/ unfamiliarity with English literature:

Question 1: How can the Saudi undergraduate EFL learners be pushed to study and appreciate English literature more successfully?

Thank you for your cooperation

The researchers

\section{Copyrights}

Copyright for this article is retained by the author(s), with first publication rights granted to the journal.

This is an open-access article distributed under the terms and conditions of the Creative Commons Attribution license (http://creativecommons.org/licenses/by/4.0/). 